ADVANCE RESEARCH JOURNAL OF SOCIAL SCIENCE
$\begin{gathered}\text { ReSEARCH } \\ \text { ARTICLE }\end{gathered}$ $\begin{gathered}\begin{array}{c}\text { Volume 11 | Issue 2 | December, 2020 | 43-46 } \\ \text { ISSN-0976-5611 }\end{array} \\ \text { DOI: 10.15740/HAS/ARJSS/11.2/43-46 }\end{gathered}$

\title{
Social maturity of adolescents
}

Leishon Shangjam*, Sampreety Gogoi and Tulika Borah

Department of Human Development and Family Studies, College of Community Science, Assam Agricultural University, Jorhat (Assam) India

(Email : leishon.shangjam@gmail.com; samprity.gogoi@aau.ac.in)

\section{ARTICLE INFO :}

$\begin{array}{lll}\text { Received } & : & 08.07 .2020 \\ \text { Revised } & : & 16.08 .2020 \\ \text { Accepted } & : & 10.09 .2020\end{array}$

\section{KEY WORDS :}

Adolescents, Social maturity, Personal adequacy, Interpersonal adequacy, Social adequacy

\section{HOW TO CITE THIS ARTICLE :}

Shangjam, Leishon, Gogoi, Sampreety and Borah, Tulika (2020). Social maturity of adolescents. Adv. Res. J. Soc. Sci., 11 (2): 43-46, DOI: 10.15740/HAS/ARJSS/ 11.2/43-46.Copyright@2020:Hind AgriHorticultural Society

*Author for correspondence

\begin{abstract}
Adolescence is the bridge between childhood and adulthood and it describes the social behaviour and characteristics. When an individual has the ability to respond to the environment in an appropriate manner then one shows social maturity. Adolescents grow into social maturity, when they learn to manage a group situation with skill and confidence, with this background the present study entitled, "Social maturity of adolescents" was undertaken during the year 2017-2019. The study was conducted to assess the social maturity of adolescents. A total of 120 adolescents were selected randomly from four schools of Ukhrul sub-division, Manipur. A questionnaire was prepared to collect the background information of the respondents. To measure the social maturity of adolescents, a structured standardized tools named 'Social Maturity Scale' developed by Dr. Nalini Rao (1971) revised in 2009 was used. The findings of the study revealed that majority of the adolescents were at average level maturity.
\end{abstract}

